\title{
Confidentiality Code
}

National Cancer Institute

\section{Source}

National Cancer Institute. Confidentiality Code. NCI Thesaurus. Code C93538.

A coded value specifying the degree of privacy applicable for the entity. 